Correction

\title{
Correction: Li, J.; et al. The Impact of Lake Water Quality on the Performance of Mature Artificial Recharge Ponds. Water 2019, 11, 1991
}

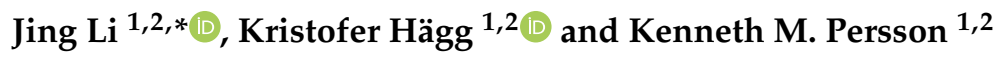 \\ 1 Division of Water Resources Engineering, Faculty of Engineering LTH, Lund University, John Ericssons Väg 1, \\ V-Hus, 22100 Lund, Sweden; kristofer.hagg@tvrl.lth.se (K.H.); kenneth_m.persson@tvrl.lth.se (K.M.P.) \\ 2 Sweden Water Research AB, Ideon Science Park, Scheelevägen 15, 22370 Lund, Sweden \\ * Correspondence: jing.li@tvrl.lth.se; Tel.: +46-46-222-83-28
}

Received: 3 March 2020; Accepted: 3 March 2020; Published: 16 June 2020

check for updates

The authors wish to make the following corrections to this paper [1]:

In Figure 8, the legend on the left side should be "Lake Vomb, After contact filter treatment, Contact filter pond and Contact filter well", as shown in the below figure.

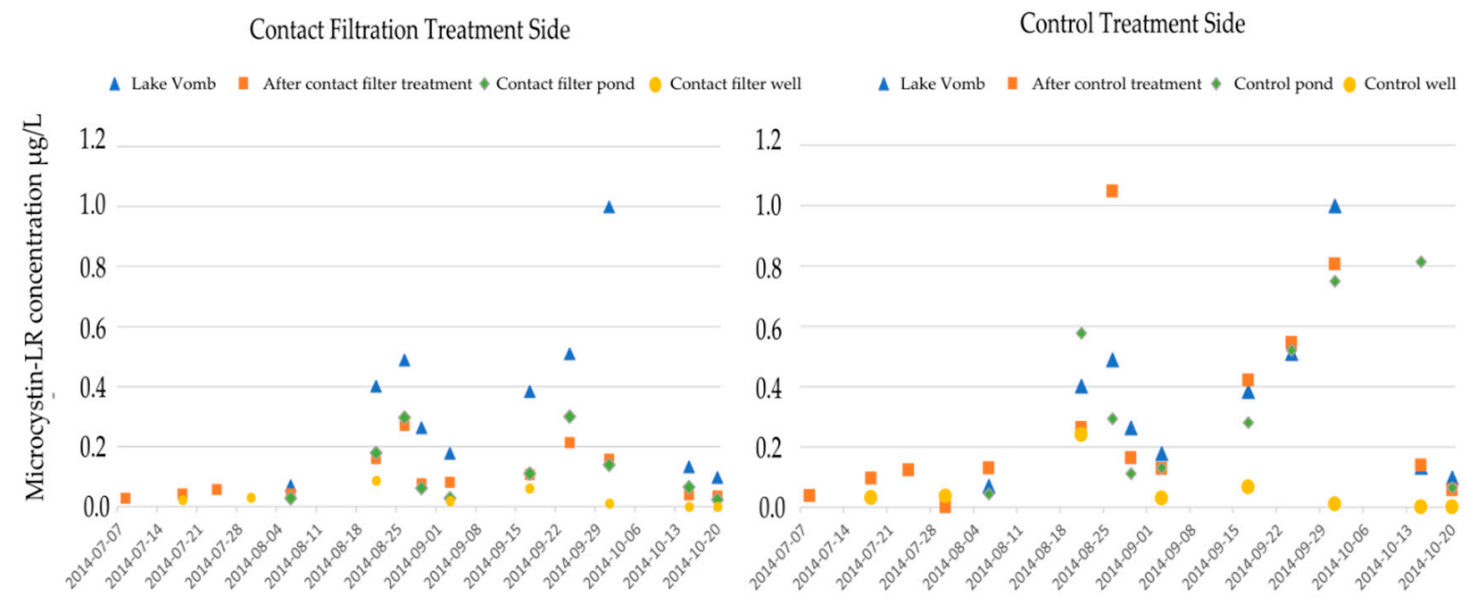

The authors would like to apologize for any inconvenience caused to the readers by these changes.

\section{Reference}

1. Li, J.; Hägg, K.; Persson, K.M. The Impact of Lake Water Quality on the Performance of Mature Artificial Recharge Ponds. Water 2019, 11, 1991. [CrossRef]

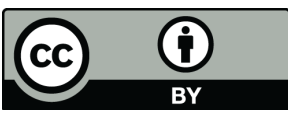

(C) 2020 by the authors. Licensee MDPI, Basel, Switzerland. This article is an open access article distributed under the terms and conditions of the Creative Commons Attribution (CC BY) license (http://creativecommons.org/licenses/by/4.0/). 